\title{
Livsmening, krise og optimisme under COVID-19-epidemiens første nedlukning
}

\author{
Artikel 6 \\ HEIDI FRØLUND PEDERSEN \& PETER LA COUR
}

\begin{abstract}
ENGLISH ABSTRACT: This article investigates how the lockdown during the early phase of the COVID-19 pandemic affected the Danish population existentially in terms of experienced meaning in life or crisis of meaning, and whether specific socio-demographic characteristics and mental health were associated with these existential factors. The study finds that a majority of Danes express hope and trust in secular resources such as science, authorities, and humanity. This was also prevalent among participants who described themselves as religious. One-fourth of participants reported experiencing increased meaning in life, while another fourth reported experiencing a crisis of meaning. Especially young participants reported increased meaningfulness, but also higher crisis of meaning. Reporting a crisis of meaning was moderately associated with poorer mental health, as well as fear of contamination and lower education and income. This may indicate that individuals having fewer socio-economic resources are more vulnerable in a crisis like this.
\end{abstract}

DANSK RESUMÉ: I denne artikel undersøges det, hvorvidt COVID-19-krisens første nedlukning har påvirket danskernes eksistentielt i form øget oplevelse af mening $i$ livet og eller givet anledning til eksistentiel krise, samt om bestemte karakteristika er forbundet hermed. Vi fandt, at et stort flertal gav udtryk for håb og tillid til sekulxre ressourcer såsom videnskaben, myndigheder, og menneskeheden, også blandt personer med en stærk religiøsitet. En fjerdedel af deltagerne gav udtryk for at opleve mere mening i livet, mens en fjerdedel gav udtryk for eksistentiel krise. Sxrligt unge gav udtryk for både øget meningsfuldhed, men også øget krise. Angivelse af krise var kraftigt korreleret til dårligere mentalt velbefindende, men også til frygt for smitte samt lavere uddannelse og indkomst, hoilket indikerer at personer med færre socio-økonomiske ressourcer synes at være mere sårbare i en krisetid som denne.

KEY WORDS: COVID-19; COVID-19 and existential well-being; COVID-19-and religion; COVID-19 and crisis of meaning

Krisetider antages at sætte eksistentielle forhold og alment velbefindende under pres, som beskrevet i artiklen om "Undersøgelsens historiske og teoretiske baggrund" (nr. 
3). Det er sandsynligt, at personer vil søge at tilpasse sig krisen gennem såvel eksistentielle orienteringer (søge mening i livet), ligesom religiøse tolkninger og adfærd kan anvendes i tilpasningen under en krise. Under COVID-19 pandemien er der flere forhold, som kan anspore eksistentielle tanker og reaktioner: Den forøgede risiko for at blive smittet og få et alvorligt sygdomsforløb med døden til følge må angiveligt give anledning til overvejelse om egen eksistens eller ens nærmeste pårørendes risiko for at blive alvorligt syge og dø. Overvejelser om mening i livet og hvordan man prioriterer sin tid kan tænkes at komme i spil.

De kraftige restriktioner under nedlukningen ændrede mulighederne for fri livsførelse på mange planer og greb ind i grundlæggende menneskelige behov for social kontakt, autonomi og frihed. Dette kan tænkes at have givet anledning til en øget længsel efter nærhed til andre, men også et potentielt øget konfliktniveau ift. andre. Derudover antages det, at indre konflikt $\mathrm{i}$ form af mere skyldfølelse og mindre tillid til andre også kom i spil, da alle blev pålagt et ansvar for at tage vare på hinanden gennem ansvarsfuld adfærd (afspritning/håndvask, holde afstand, hoste i ærmet).

Den potentielle økonomiske kollaps i samfundet som følge af kraftige restriktioner har givet en usikkerhed ift. fremtiden og tænkes at indebære et øget konfliktniveau (både indre og ydre) og usikkerhed i forhold til egen eksistens.

Den ukendte tidsfaktor, at ingen har kunnet spå om forløbet og tidsrammen for COVID-19-krisen, kan medføre usikkerhed og angst i befolkningen. Selvom livet i bund og grund er uforudsigeligt, så opbygger de fleste en fornemmelse af kontrol over tilværelsen, som dog udfordres under krisetider som denne. Som et forsøg på at opnå kontrol tænkes det derfor, at mennesker reagerer ved fæste tillid til mulige løsninger på krisen, men også arbejder med egen accept (eller ikke accept) af tilværelsens uforudsigelighed.

Med denne cocktail af forskellige umiddelbare og fremtidige konsekvenser er det vores bud, at ingen har undgået at opleve deres eksistentielle orienteringer under pres, men at det er meget forskelligt, hvordan det har givet sig udtryk, og hvordan den enkelte har reageret og tilpasset sig krisen i den første fase af pandemien. Som følge af de forskellige konsekvenser, COVID-19-pandemien har medført, blev eksistentielle forhold operationaliseret ved at anvende en blanding validerede spørgsmål, kendt fra andre sammenhænge samt nyformulerede spørgsmål skræddersyet til COVID-19 pandemien.

I dette kapitel vil vi dels undersøge graden af oplevet mening eller eksistentiel krise blandt deltagerne og se på, hvordan dette relaterer sig til mentalt velbefindende. Herunder vil vi undersøge, om religiøse forhold gør sig gældende. Derudover vil vi undersøge, om der findes bestemte typer af reaktionsmønstre, der har fællestræk, og hvilke andre forhold - sekulære som religiøse - disse kan korrelere med. 


\section{Oplevede danskerne mere eller mindre mening eller krise under nedlukningen?}

To spørgsmål spurgte direkte til oplevet mening og oplevet meningskrise og er oplistet i Figur 6.1.

Det gælder respondenternes tilslutning til følgende udsagn: "Siden coronavirus pandemien kom til Danmark har jeg oplevet en eksistentiel krise" og "Siden coronavirus pandemien kom til Danmark oplever jeg mere mening og formål i mit liv".

Figur 6.1. Oplevet mening og eksistentiel krise.

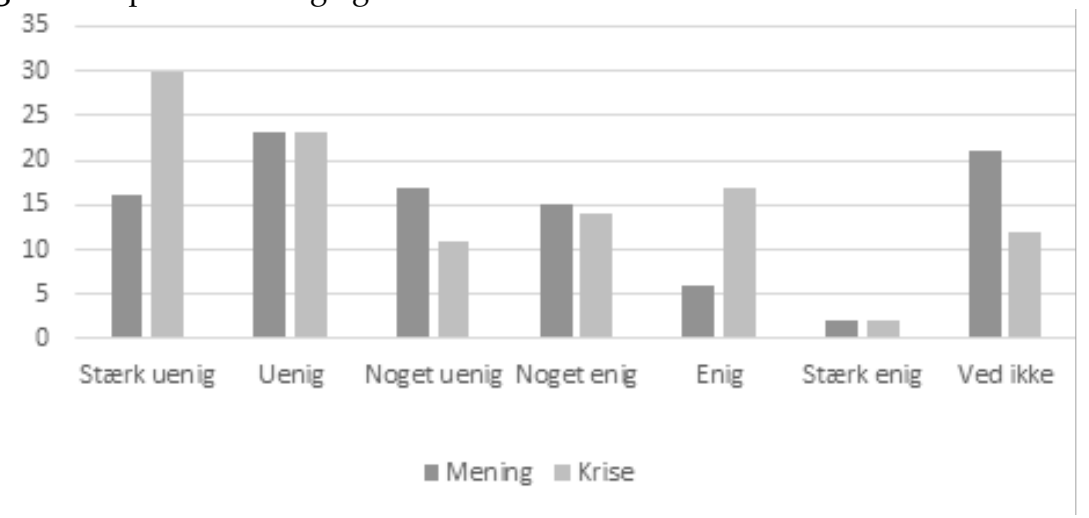

Procent. $N=1.538$

Ud fra figur 6.1. ses, at $23 \%$ af deltagerne oplevede noget eller meget mere mening og formål i deres liv, mens $23 \%$ har oplevet at være i en eksistentiel krise i større eller mindre omfang. Beregnes aldersfordelinger på disse spørgsmål, ses signifikante forskelle på begge udsagn med Analysis of Variance-beregning (ANOVA). Der er forskelle mellem aldersgrupper for dem, der oplever mere mening og formål, men ikke noget bestemt mønster. Dog rapporterer de yngste (18-24 år) signifikant mere øget mening og formål i livet end den ældste aldersgruppe (+5+ år) (diff. 0.4, $p<0.22,95 \%$ CI: 0.04; 0.8). For de personer, der har oplevet en eksistentiel meningskrise, er det imidlertid ganske klart, at meningskrisen er mere tilstede, jo yngre man er. De to yngste aldersgrupper (18-24 år og 25-34 år) rapporterer signifikant mere eksistentiel krise sammenlignet med alle andre grupper. Aldersfordelingen ses i figur 6.2. 
Figur 6.2. Oplevet mening og eksistentiel krise fordelt på alder. Gennemsnit

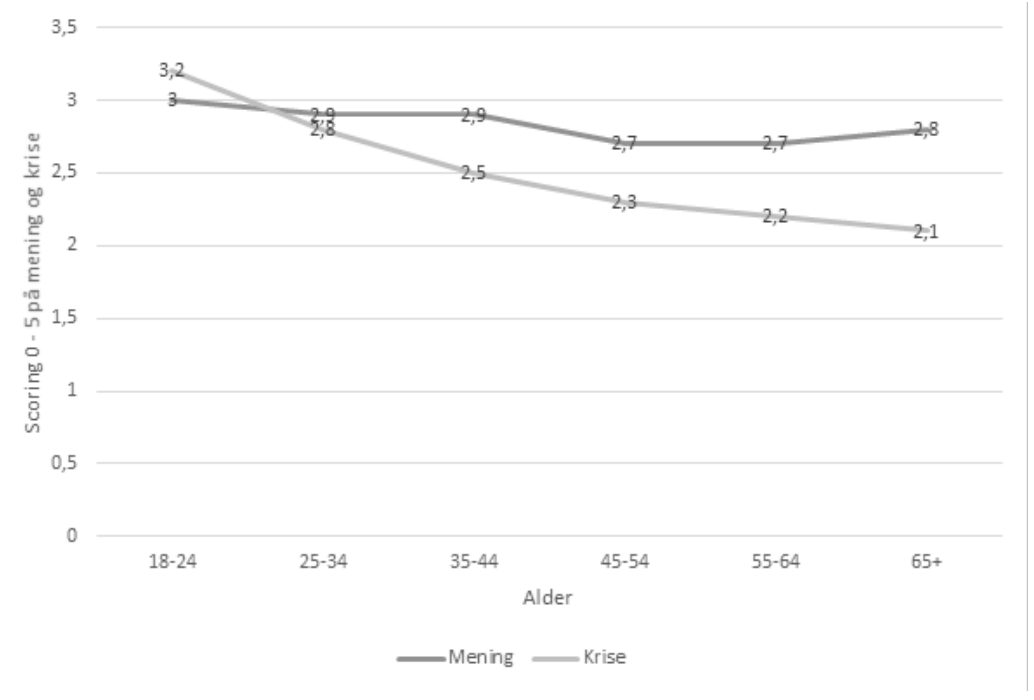

Beregnes kønsfordelinger for dem, der har oplevet mere mening eller krise, ses kun én signifikant kønsforskel (t-test), nemlig at det er mændene (mean = 2.9, sd 1.4), der i højere grad end kvinderne (mean $=2.7$, sd 1.3) oplever mere mening og formål $(\mathrm{t}=$ $2.7, p<0.007,95 \%$ CI: $-0.4 ;-0.1)$.

Det store flertal har ikke oplevet større mening og formål. Det afspejler måske, at hverdagen under nedlukningen blev vendt på hovedet og adgangen til det, som normalt gav mening og formål, blev afskåret. Nedlukningen resulterede i, at nogle forældre skulle varetage arbejde, børnepasning og skoleundervisning samtidig og har måske ikke oplevet, at de har kunnet lykkes tilstrækkeligt med nogle af rollerne. Den sparsomme sociale kontakt ramte alle; men nogle grupper som unge eller enlige ældre har måske følt sig særligt ramt. Visse grupper blev sendt væk fra arbejdspladsen eller mistede helt deres job og dermed deres arbejdsidentitet og samværet med kollegaer. Alle aldersgrupper har været afskåret fra normale fritidsaktiviteter som sport, kultur og cafe- og restaurantbesøg - alt sammen noget som for de fleste giver indhold i hverdagen og kan være kilder til mening. Det er derfor ikke underligt, at vi ser en majoritet, der er uenige $i$, at deres liv opleves mere fyldt med mening og formål.

\section{Oplevet meningsfuldhed}

Næsten en fjerdedel af danskerne har i modsætning hertil under nedlukningen oplevet af få større mening og formål i deres liv, mens det ikke er tilfældet for de 3/4 af deltagerne. Tallet afspejler formentlig, at den gruppe, som har oplevet øget meningsfuldhed, i højere grad har fået øget opmærksomhed på de nære ting og relationer. Det kan tænkes, at en krise gør den enkelte mere opmærksom og påvirker prioriteter, så det, der opleves som vigtige kilder til mening, bliver tydeligere, og dermed påvirker den oplevede meningsfuldhed. Dette er i hvert fald teorien fra Schnell (2009; 2011), der i sine undersøgelser har fundet, at et dybere og bredere engagement i forskellige 
kilder til mening er forbundet med større oplevet meningsfuldhed. Mange blev pålagt at arbejde eller studere hjemmefra, og det kan det tænkes, at det for nogle har været muligt at bruge en større del af deres tid på flere forskellige aktiviteter ud over arbejde bl.a. som følge af reduceret transporttid og en større fleksibilitet i tiden derhjemme. Andre har måske oplevet nedlukningen af sociale aktiviteter og sociale forpligtigelser som en lettelse, der har givet mere tid til dem selv. For nogen familier har hjemmeskolingen og aflysningen af sport og fritid måske været en mulighed for mere nærvær med familien mod en ellers travl hverdag med mange timer uden for hjemmet.

Vi får lidt mere fornemmelse af, hvad corona-krisen har betydet for hverdagslivet, hvis vi kigger på et af de åbne spørgsmål, som blev stillet til deltagerne: "Hvilken ændring $i$ dine sociale relationer og aktiviteter under corona virus pandemien har påvirket dig mest". Ved hjælp af en word-crow-analyse finder vi, at følgende ord er nævnt oftest: “Familie", “Venner", “Børn", “Kram", “Besøge" og “Tæt". Det springer i øjnene, at det alle er ord, som knytter sig til socialt samvær og ikke ord der knytter sig til andre aktiviteter som fritid eller arbejde.

Figur 6.3. Word-crowd-analyse af oplevede ændringer

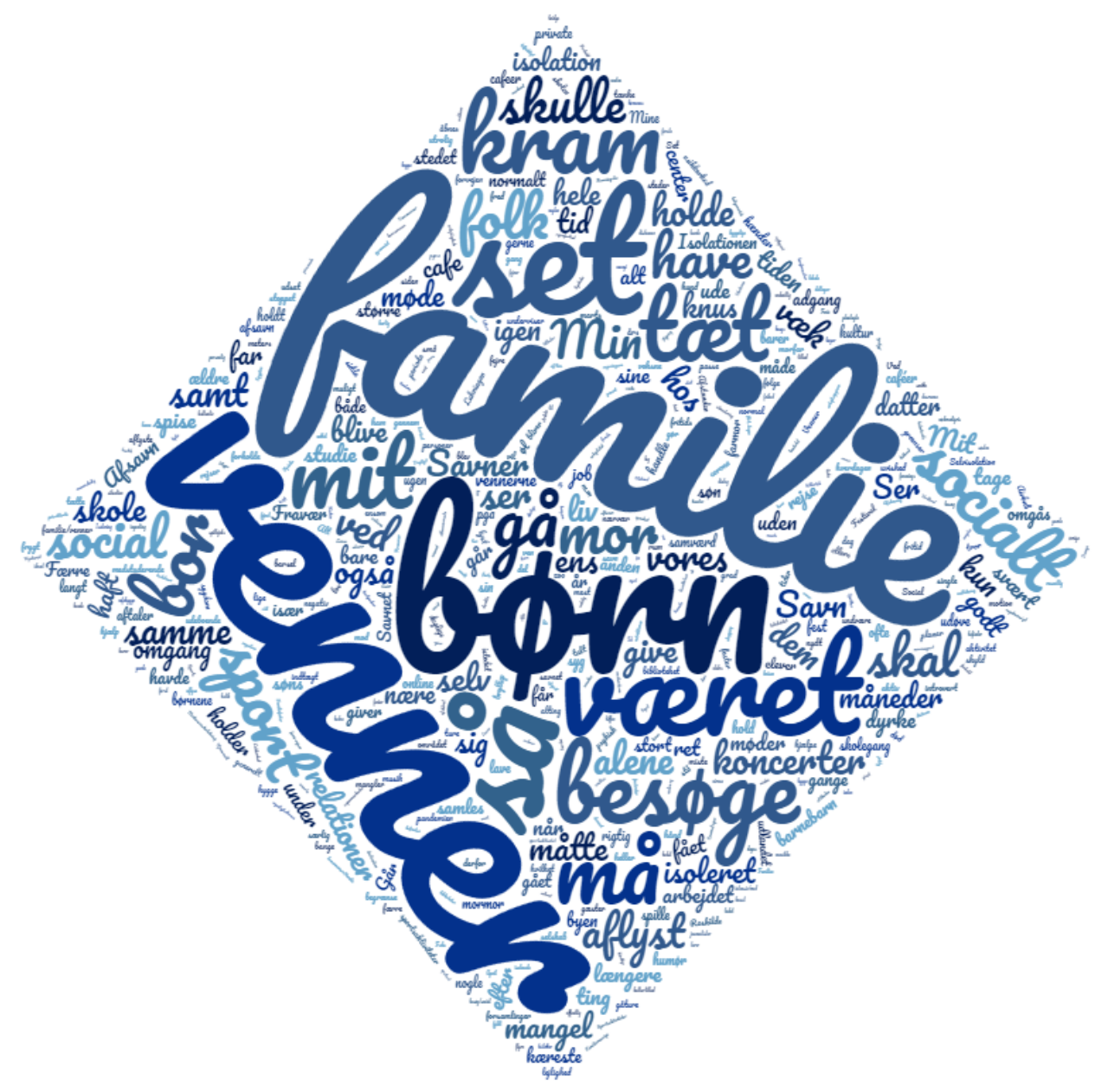


Når vi kigger på angivelserne, er det gennemgående, at deltagerne savner familiebesøg, samværet med hinanden og oplever restriktionerne om afstand som indgribende i forhold til normale sociale samværsformer, eksempelvis at give hånd og kram. Nogle citater kan gives som eksempler: "Afsavn af alle de aktiviteter jeg plejer at deltage i. At give mine nærmeste knus og kram, og se mine venner/familie"; "At man ikke kan kramme og være tæt". Der fremkommer også udsagn om afsavnet til særlige livsbegivenheder, som ikke kan gøres om, eksempelvis bryllupper og studenterfester (som var særligt debatteret i genåbningens første fase): “Alle planer for min kommende studentertid er påvirket af corona og derfor får jeg ikke lov til at fejre det som alle andre før mig har gjort det". I materialet nævnes det begrænsede kulturliv, sportsliv og andet fritidsliv, ligesom deltagerne også nævner ændrede arbejdsbetingelser som noget, der påvirker meget. Med hensyn til, hvilke afsavn deltagerne har oplevet som værst, kan henvises til artiklen om “COVID-19 og religion" (nr. 4), der har behandlet dette kvantitativt. Dog finder vi også i materialet, at nogen finder positive ting ved ændringerne. Et citateksempel kunne være: "Ikke at kunne deltage i mit første barnebarns 1-års fødselsdag. Savner at kramme familie og venner og at kunne mødes til hyggeligt samvær på caféer, men som lettere introvert har det også været skønt at kunne få mere tid alene". Som citatet anskueliggør, så opleves pandemiens afsavn tydeligt; men der er også plads til nyfortolkning og ændrede prioriteter for nogen, som kan opleves positivt. Dette underbygges ved besvarelserne på spørgsmålet: "Jeg har været mere i stand til at bruge tid på det, der er væsentligt for mig".

Figur 6.4. Bruger tid på det der er væsentligt for mig. Procent.

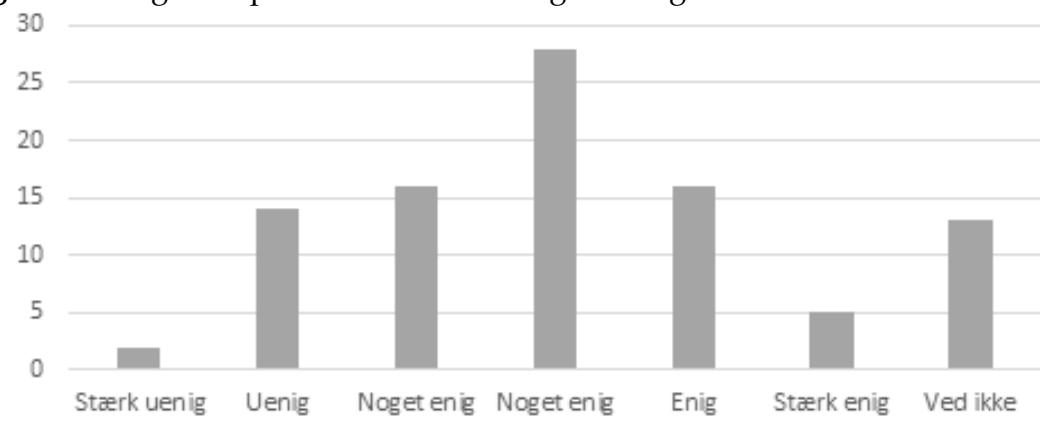

n Bruger mere tid på det væsentlige

Af figur 6.4 ser vi, at knap 50\% af deltagerne i større eller mindre grad oplever, at de har kunnet bruge mere tid på det, som er væsentligt for dem. Vi kan undersøge, om dette udsagn er relateret til en øget meningsoplevelse ved at ved at korrelere det med deltagernes svar på spørgsmålet om øget mening.

Korrelationen mellem de to spørgsmål er $\mathrm{r}=0.58(\mathrm{p}<0.01)$, hvilket er temmelig meget. Der er altså en klar sammenhæng mellem personens oplevelse af at prioritere, hvad der er væsentligt i livet, og personens selvvurderede oplevelse af meningsfuldhed. Vi er dog ikke i stand til at tolke, om det var personer, der før pandemien havde en generelt høj meningsoplevelse, som under krisen var i stand til at transformere krisens omstændigheder til det bedste eller det modsatte: Om der snarere var 
personer, som oplevede lav meningsfuldhed før krisen, som under nedlukningen oplevede, at den ændrede hverdag gav anledning til at engagere sig mere i væsentlige ting. Det er værd at bemærke, at en stor andel af personer (21\%) har valgt at svare "Ved ikke" til spørgsmålet om mere mening (se figur 6.1). Vi ved ikke, om disse personer enten ikke ønsker at svare, eller om de reelt ikke har overvejet dette spørgsmål.

\section{Oplevet eksistentiel krise}

Omkring en fjerdedel af danskerne har oplevet en større eller (især) mindre meningskrise under nedlukningen. Dette gælder særligt de yngste aldersgrupper. Under nedlukningen har medier og eksperter påpeget, at det særligt har været de unge, som blev ramt hårdt af restriktionerne, der i vid udstrækning lukkede adgangen til deres sociale liv (lukkede undervisningsinstitutioner, lukkede caféer og barer, lukket kulturliv og fritidsliv). Meget af det, som udgør livet for en ung under 30, var stort set ikke eksisterende. Tallene afspejler formentlig også, at COVID-19-krisen også blev et personligt anliggende, hvor fremtiden var blevet usikker, og hvor forventningerne om hverdagens stabilitet er sat på prøve. Det kan tænkes, at unge på den korte bane har oplevet sig truet eksistentielt af usikkerhed om egen nære fremtid og på den lange bane har følt sig truet af en potentielt mere ustabil verden som følge af pandemien.

Hvis vi korrelerer spørgsmålet om oplevet eksistentiel krise og spørgsmålet om at kunne bruge mere tid på det, som er væsentlig for én efter pandemien kom til Danmark, ser vi en korrelation på $\mathrm{r}=0.08(\mathrm{p}<0.01)$. Der er altså langt færre i eksistentiel krise, der oplever at kunne prioritere deres tid bedre, mens det var udpræget tilfældet for dem, som har oplevet øget mening og formål i livet. Dog viser korrelationen, at en eksistentiel krise ikke udelukker, at personer engagerer sig mere i væsentlige ting i livet. Vi kan formentlig tolke det således, at en oplevet eksistentiel krise måske netop giver anledning til, at man anvender ekstra tid på det væsentlige. Dette vil forhåbentlig kunne undersøges ved et longitudinelt studie, hvorfor vi er spændte på at følge deltagernes svar ved anden og tredje bølge af denne undersøgelse. Det kan give et klarere svar på, hvorvidt personer, der ved første besvarelse angav at være i en høj eksistentiel krise, også angiver et større engagement i det, som er vigtigt for dem ved de senere tidsmålinger. Eller om det nærmere er omvendt, at personer i eksistentiel krise over tid mister engagementet i væsentlige prioriteter i livet.

\section{Var det de mentalt sunde, der oplevede mere mening eller krise i livet?}

Fra litteraturen ved vi, at meningsfuldhed og meningskrise er korrelateret til mental sundhed. Vi har derfor en hypotese om, at det især er de mentalt sunde personer, der rapporterede en højere mening i livet, mens eksistentiel krise er forbundet med dårligere mentalt velbefindende. Vi kan teste dette ved at korrelere oplevet mening og oplevet krise med målet for mentalt velbefindende (WHO-5, se kapitel 5 for en ud- 
dybning af formulering og scores). I tabel 6.5 vises korrelationen med "ved ikke" kategorierne fjernet. Vi ser, at personer med en større grad af oplevet mening og formål efter pandemien kom til Danmark, også giver udtryk for et bedre mentalt velbefindende. Styrken af denne korrelation $(r=0.12)$ er ikke så stor i sammenligning med, hvad andre studier typisk finder; men korrelationens retning styrker hypotesen. Man kan tolke resultatet på to måder: At personer i bedre mental balance i højere grad var i stand til at opleve mening og formål i livet selv under krisens tidlige nedlukning. Det kan dog også tolkes således, at en tydelig oplevelse af mening og formål i livet fungerer som et bolværk, der afværger de psykiske konsekvenser som en krise som COVID-19-pandemien medfører. Vi kan ikke afdække dette forhold, da vi kun har en enkelt måling og ikke kan sammenligne deltagernes besvarelser med deres tilstand før krisen opstod. Vi håber på mulighed for uddybning i undersøgelsens anden og tredje fase.

Tabel 6.5. Korrelation mellem mentalt velbefindende, oplevet mening og eksistentiel krise. Pearsons korrelation.

\begin{tabular}{ll}
\hline Siden coronavirus-pandemien kom til Danmark... & $\begin{array}{l}\text { Mentalt velbefindende } \\
(\text { WHO-5) }\end{array}$ \\
\hline ...oplever jeg mere mening og formål i mit liv $(\mathrm{n}=1204)$ & $0.12^{* *}$ \\
$\ldots$..har jeg oplevet en eksistentiel krise $(\mathrm{n}=1334)$ & $-0.33^{* *}$ \\
\hline
\end{tabular}

Korrelationen mellem meningskrise og dårligere mentalt helbred var kraftigere korreleret $(r=0.33)$. Det svarer til, hvad andre studier finder: At en eksistentiel krise er stærkere korreleret til dårligt mentalt helbred (angst, depression, distress) end oplevet meningsfuldhed er til godt mentalt helbred (Schnell 2009; Damasio et al. 2013; Pedersen et al. 2018; Sørensen et al. 2018). Deraf kan vi tolke, at en eksistentiel krise er en tilstand, der rækker gennemgribende ind i personens psykiske velbefindende. Som vi har set, er det særligt de unge, der oplever en meningskrise i sammenligning med ældre. Det er også de unge (og særligt unge kvinder), der er mentalt sårbare (se kapitel 5), hvorfor resultaterne stemmer godt overens. Vi har dog stadig ingen mulighed for at undersøge, om de, der oplevede en øget eksistentiel krise under nedlukningen, også var særligt mentalt sårbare før krisen, eller i hvor høj grad det er den eksistentielle krise under COVID-pandemien, der har medført et dårligere psykisk helbred.

\section{Konflikt, skyld og accept}

I spørgeskemaet spurgte vi også ind til eksistentielle grundtemaer som accept, skyld og oplevet konflikt i relation til andre. Vi ser af tabel 6.6 , at $23 \%$ af deltagerne har oplevet et øget konfliktniveau (i større eller mindre grad) i forhold til andre mennesker. Vi kan ikke sammenligne med niveauerne inden pandemien; men vi tolker resultatet som forholdsvist markant. De er tænkeligt, at den øgede tid i hjemmet med ens nærmeste i samspil med en presset situation for nogle har givet anledning til 
større spændinger. Under nedlukningen udtrykte både social- og sundhedsministeren bekymring for, at udsatte kvinder og børn kunne være i øget i risiko for psykisk og fysisk vold i hjemmet, fordi de var tvunget til at være hjemme med partnere/fædre, der ikke kunne aflede frustrationer andre steder hen end mod de nærmeste.

Tabel 6.6. Konflikt, mindre forbundethed tillid og accept under COVID-19

\begin{tabular}{|c|c|c|c|c|c|c|c|}
\hline $\begin{array}{l}\text { Siden coronavirus-pandemien kom } \\
\text { til Danmark... }\end{array}$ & $\begin{array}{l}\text { Stærkt } \\
\text { uenig }\end{array}$ & Uenig & $\begin{array}{l}\text { Noget } \\
\text { uenig }\end{array}$ & $\begin{array}{l}\text { Noget } \\
\text { enig }\end{array}$ & Enig & $\begin{array}{l}\text { Stærkt } \\
\text { enig }\end{array}$ & Ved ikke \\
\hline $\begin{array}{l}\text {... har jeg følt mig mere i konflikt } \\
\text { med eller uenig med andre menne- } \\
\text { sker }\end{array}$ & $23 \%$ & $30 \%$ & $12 \%$ & $15 \%$ & $6 \%$ & $2 \%$ & $12 \%$ \\
\hline $\begin{array}{l}\ldots . \text { har jeg følt mig mindre forbun- } \\
\text { det med andre mennesker }\end{array}$ & $8 \%$ & $17 \%$ & $14 \%$ & $22 \%$ & $20 \%$ & $7 \%$ & $12 \%$ \\
\hline $\begin{array}{l}\text {... har jeg følt mere dårlig samvit- } \\
\text { tighed }\end{array}$ & $35 \%$ & $30 \%$ & $9 \%$ & $10 \%$ & $4 \%$ & $1 \%$ & $12 \%$ \\
\hline $\begin{array}{l}\ldots . \text { har jeg følt mig mere tillidsfuld i } \\
\text { forhold til fremtiden }\end{array}$ & $10 \%$ & $21 \%$ & $23 \%$ & $15 \%$ & $6 \%$ & $1 \%$ & $24 \%$ \\
\hline $\begin{array}{l}\text {... er jeg blevet bedre til at accep- } \\
\text { tere tilværelsens vilkår }\end{array}$ & $6 \%$ & $8 \%$ & $12 \%$ & $33 \%$ & $22 \%$ & $4 \%$ & $17 \%$ \\
\hline
\end{tabular}

Vi ser også, at næsten halvdelen oplever sig mindre forbundet med andre mennesker. Det giver jo i sig selv god mening, fordi den sociale kontakt har været kraftigt reduceret. Dog ser vi også at en forholdsvis stor del af danskerne (39\%) rapporterer, at dette ikke er tilfældet, hvorfor det for nogen måske har givet anledning til mere nærhed og kvalitet i de relationer, man så trods alt har set eller haft kontakt til under nedlukningen.

På spørgsmålet om øget dårlig samvittighed som følge af pandemien ser vi, at 15\% i nogen eller høj grad har oplevet mere dårlig samvittighed. Det er umiddelbart svært at tolke, hvad denne samvittighedsfølelse dækker over. Én hypotese kunne være, at den dårlige samvittighed kan være afledt af en generel frustration på baggrund af krisen, som giver sig udslag i konflikter med andre. En anden hypotese kunne være, at respondenterne føler skyld over potentielt at kunne bringe smitten videre, som kan tænkes videre at afspejle sig i rituel adfærd omkring øget håndvask og afspritning. Vi kan teste de to hypoteser ved at korrelere de forskellige udsagn. Når vi korrelerer oplevet konflikt til andre og oplevet dårlig samvittighed finder vi en korrelation på $r=0.42(p<0.01)$, hvilket er rimelig højt. Der synes altså at være hold i hypotesen om, at ydre og indre konflikt er forbundet i dette tilfælde. Der er noget, som tyder på, at pandemiens konsekvenser for nogle har givet anledning til øget konflikt $\mathrm{i}$ indbyrdes relationer og måske deraf en øget dårlig samvittighed.

Til gengæld er der ingen sammenhæng mellem dårlig samvittighed og håndvask eller afspritning. Vi kan derfor afvise, at der skulle være dårlig samvittighed, som danskerne forsøger at dæmpe ved øget håndvaskning eller afspritning.

Som en modpol til oplevet indre og ydre konflikter spurgte vi ind til accept af tilværelsens vilkår og oplevelsen af tillid til fremtiden. På spørgsmålet om accept svarer 
knap $60 \%$ af deltagerne bekræftende på dette udsagn. I forhold til øget tillid til fremtiden ser vi, at $22 \%$ svarer bekræftende på dette, mens over halvdelen (54\%) ser mere pessimistisk på fremtiden.

\section{Håb og tillid til sekulære løsninger på pandemien}

Som reaktion på kriser som COVID-19-pandemien er det forventeligt, at mennesker rækker ud efter løsninger til at genoprette normalen og genfinde en form for oplevet kontrol over tilværelsen. I artiklen om "COVID-19 og religion" (nr. 4) blev det undersøgt, hvorvidt danskerne er blevet mere religiøse under krisen, og man fandt her, at dette ikke var tilfældet. Danskerne har ikke vendt sig til religion for at opnå sikkerhed og kontrol. Det er mere sandsynligt, at vi i et højt sekulariseret og humanistisk præget land som Danmark vil se en øget tiltro til myndigheder, videnskaben og det fællesmenneskelige ansvar. Under pandemien har myndighederne anvist detaljerede guidelines for adfærd, der kan være med til at give den enkelte en fornemmelse af kontrol over den nære hverdag - som også gavner det store fællesskab. Myndighederne har kommunikeret tydeligt om de løsninger, der arbejdes på i forhold til udvikling af vaccinen og givet kredibilitet til videnskaben ved eksempelvis at lade lederen af Statens Serum Institut, Kåre Mølbak, og direktøren for Sundhedsstyrelsen, Søren Brostrøm, få en del taletid på de hyppige pressemøder under nedlukningen. Derudover har kommunikationen fra myndighederne været gennemsyret af en anmodning om at stå sammen i et fællesmenneskeligt ansvar. Vi var derfor nysgerrige på, hvor høj tillid befolkningen udviste over for myndighederne, og hvor meget tillid der var til videnskaben og menneskehedens evne til at stå sammen som sådan, tabel 6.7.

Tabel 6.7 Tillid til myndigheder, videnskab og menneskeheden.

\begin{tabular}{|c|c|c|c|c|c|c|c|c|}
\hline $\begin{array}{l}\text { Siden coronavirus-pandemien } \\
\text { kom til Danmark... }\end{array}$ & $\begin{array}{l}\text { Stærkt } \\
\text { uenig }\end{array}$ & Uenig & $\begin{array}{l}\text { Noget } \\
\text { uenig }\end{array}$ & $\begin{array}{l}\text { Noget } \\
\text { enig }\end{array}$ & Enig & $\begin{array}{l}\text { Stærkt } \\
\text { enig }\end{array}$ & & Ved ikke \\
\hline $\begin{array}{l}\ldots \text { har jeg følt mig mere til- } \\
\text { lidsfuld overfor myndigheder } \\
\text { og autoriteter }\end{array}$ & $8 \%$ & $11 \%$ & $15 \%$ & $30 \%$ & $19 \%$ & $4 \%$ & & $13 \%$ \\
\hline $\begin{array}{l}\text {... er jeg blevet mere overbe- } \\
\text { vist om videnskabens evne til } \\
\text { at løse store kriser. }\end{array}$ & $4 \%$ & $6 \%$ & $9 \%$ & $33 \%$ & $23 \%$ & $5 \%$ & & $20 \%$ \\
\hline $\begin{array}{l}\text {... er jeg blevet mere overbe- } \\
\text { vist om menneskehedens } \\
\text { evne til at komme gennem } \\
\text { store kriser }\end{array}$ & $3 \%$ & $6 \%$ & $8 \%$ & $32 \%$ & $29 \%$ & 6 & $\%$ & 16 \\
\hline
\end{tabular}

Af tabel 6.7 fremgår det, at over halvdelen (53\%) oplever en øget tillid til myndigheder og autoriteter. Lidt færre, men $\operatorname{dog} 61 \%$ er blevet mere overbeviste om videnskabens evne til at løse store kriser, og endelig ser vi, at 2/3 er blevet mere overbeviste om menneskehedens evne til at komme igennem store kriser. Det ser altså ud til, at de fleste danskerne i høj grad kaster deres forventninger og håb om en redning fra krisen på sekulære ressourcer. Hvordan forholder disse overbevisninger sig til, hvad 
man tror er årsagen til pandemien? Én hypotese kunne være, at personer, der opfatter pandemien som et led $\mathrm{i}$, at guddommelige/åndelige kræfter reagerer på menneskelig adfærd, fæster mindre tiltro til myndigheder, videnskaben og menneskeheden. En anden hypotese kunne være, at personer, der opfatter pandemien som resultat af tilfældigheder eller menneskelig adfærd, som kan forklares naturvidenskabeligt, vil i højere grad vil fæste tiltro til særligt videnskaben. Vi undersøgte disse hypoteser ved at korrelere udsagnene fra tabel 6.7 med spørgsmålet om, hvilken årsag man tilskriver pandemien.

Hypotesen om, at personer der tror pandemien skyldes åndelige kræfter eller en guddommelig plan fæster mindre tillid til sekulære ressourcer som myndigheder, videnskab og menneskeheden, blev ikke bekræftet. Tværtimod fandt analysen det modsatte: en lille, men signifikant positiv korrelation mellem disse overbevisninger (hhv. $r=0.08$ og $r=0.09, p<0.01$ ) og en øget tillid til myndigheder og autoriteter. Det kan selvfølgelig diskuteres, om der i begrebet "autoriteter" kan lægges tolkningen "guddommelige autoriteter", hvilket vi ikke på nuværende tidspunkt kan afklare.

Hypotesen at personer, der tilskriver pandemien en tilfældighed, som kan forklares videnskabeligt, også fæster mere tillid til videnskabens evne til at løse store kriser blev bekræftet, da vi fandt en signifikant positiv korrelation mellem udsagnene $(r=0.11, p<0.01)$.

På baggrund af dette resultat blev vi optagede af, hvorvidt personer med en tro eller religiøs praksis måske netop i højere grad ville fæste tillid til myndigheder, videnskaben og det fælles menneskelige, fordi studier ofte finder, at traditionsbevidst (konservativ) religiøsitet og autoritetstrofasthed hænger sammen. For at få et mål for mere traditionsbevidst konservativ religiøsitet anvendte vi religionsindexet udregnet og anvendt i artiklen om “COVID-19 og religion” (nr. 4). Vi korrelerede spørgsmål om graden af religiøsitet (se artikel 4) med de tre spørgsmål om tillid, videnskab og menneskeheden; men vi fandt ingen signifikante sammenhænge mellem graden af religiøsitet og øget tillid til videnskaben eller myndigheder. Til gengæld så vi en positiv korrelation mellem religiøsitet og større tillid til menneskehedens evne til at komme igennem kriser $(r=0.08, p<0.01)$. Der synes altså at være en tendens til at sætte sin lid til det fællesmenneskelige hos personer, der er mere religiøst orienterede og ikke en udpræget autoritetstrofasthed.

\section{Eksistentielle profiler}

I det gennemgåede så vi, at de forskellige udsagn vedrørende eksistentielle forhold viste en vis grad af sammenhæng, hvorfor det kan tænkes, at der kan skabes et billede af nogle samlende profiler eller kategorier af spørgsmål, hvor svarene typisk vil være sammenhængende. Da svarkategorierne omkring de eksistentielle udsagn er enslydende, kan vi foretage en faktoranalyse. En faktoranalyse undersøger de pågældende udsagns indbyrdes forhold, og påpeger typiske mønstre i besvarelserne. Vi kan såle- 
des undersøge, om der er distinkte eksistentielle profiler i vores datamateriale. I metodeafsnittet (Appendiks 1) er faktoranalysen beskrevet mere indgående. Vores faktoranalyse fandt frem til tre faktorer eller profiler, der her bliver navngivet som:

Profil 1: Håb og tillid. Respondenterne er her overbevist om videnskabens evne til at løse kriser og til, at menneskeheden kan komme igennem kriser; de giver udtryk for stor tillid til myndigheder og autoriteter samt til, at de er blevet bedre til at acceptere tilværelsens vilkår.

Profil 2: Krise. Respondenterne oplever en større eller mindre eksistentiel krise; de har følt mere dårlig samvittighed (skyld), følt sig mere i konflikt med andre og har følt sig mindre forbundet med andre.

Profil 3: Øget mening. Respondenterne har oplevet mere mening og formål i deres liv, har følt sig mere i stand til at bruge tid på det, der er væsentligt for dem, og følt sig mere tillidsfulde i forhold til fremtiden. De angiver også, at de er blevet bedre til at acceptere tilværelsen vilkår.

De tre profilers indhold synes umiddelbart at være sammenhængende og distinkte hver for sig, men er formentlig ikke helt uafhængige af hinanden. Sammenhænge mellem profilerne kan anskueliggøres ved at beregne, hvordan profilerne korrelerer med hinanden, se tabel 6.8.

Tabel 6.8. Korrelation mellem de tre eksistentielle profiler. Pearson correlation

\begin{tabular}{llll}
\hline & Håb og tillid & Krise & Øget mening \\
\hline Håb og tillid & 1 & $0.13^{* *}$ & $0.47^{* *}$ \\
Krise & & 1 & $0.28^{* *}$ \\
Øget mening & & & 1 \\
\hline
\end{tabular}

Som det ses, korrelerer alle tre profiler med hinanden. At de samme personer i udtalt grad giver udtryk for både håb og tillid og øget mening, kan ikke undre. På den anden side findes der personer, der har håb og tillid til fremtiden, men som ikke oplever øget mening, og personer, der oplever øget mening, men ikke er specielt tillidsfulde over for fremtiden.

Der er formentlig umiddelbart paradoksalt, at der findes en forholdsvis høj korrelation mellem øget mening og krise, fordi disse to tilstande intuitivt modstilles hinanden: Har man et meningsfyldt liv, er man ikke i eksistentiel krise. Sådan forholder det sig imidlertid ikke. Dette fund er gentaget igen og igen i litteraturen om mening i livet (se Schnell 2021). Der er nemlig tale om eksistentielle orienteringer og ikke om psykisk sundhed (trivsel), hvor tilstande som velvære og depression gensidigt udelukker hinanden. En eksistentiel krise kan måske netop være udløst af, at kilderne til mening befinder sig i livsområder, der aktuelt ikke kan udfolde sig, som for eksempel intensivt socialt liv og forbundethed under COVID-19. Der kan også være fundet nye kilder til mening undervejs (for eksempel nærhed med børnene, glæde ved færre arbejdstimer), som ikke er realisable på langt sigt. Sådanne ting vil føre til, at øget oplevelse af mening og krise optræder samtidig, fordi det erkendes, at man ikke bruger tid på det, som er mest væsentligt. Meningskrise må altså ikke forstås som identisk med depression; den har en selvstændig status (Schnell, Gerstner \& Krampe 2018), 
også selvom meningskrise ofte optræder sammen med depression, dvs. dårligt mentalt helbred.

\section{Hvem har været de udsatte under krisen?}

Fra de forudgående analyser i dette kapitel ved vi, at eksistentiel krise er negativt korreleret med mentalt helbred. Vi så, at det i særlig grad var de yngre, som var præget af både krise og dårligere mentalt helbred. Det kan dog tænkes, at også er andre grupper i samfundet er truede af eksistentiel krise. Under og efter nedlukningen har det været diskuteret, at ikke alle har haft lige gode muligheder for at håndtere og komme igennem pandemiens konsekvenser. Eksempelvis har de lavere sociale grupper været mere eksponeret for at få COVID-19, da de ofte arbejder i servicefag eller bor tættere med andre. Det er også de lavt uddannede og lavtlønnede, som har været i øget risiko for at miste deres job eller opleve væsentlige ændringer i deres jobsituation. Omvendt kan nogle persongrupper tænkes at have bedre forudsætning for at transformere krisen til mening og håb, eksempelvis de ældre (i kraft af deres erfaringer af, at kriser kan løses) eller bedre uddannede, som står mere stabilt i forhold til jobmuligheder på sigt. Det kan dog også tænkes, at andet end socio-demografi spiller en rolle, såsom de grundlæggede livssyn, der i denne undersøgelse er operationaliseret ved spørgsmål om tro og religiøsitet.

Det kan undersøges, om såvel socio-demografi som livssyn (religiøst eller spirituelt), men også graden af angst for smitte falder sammen med de tre eksistentielle profiler. Vi har korreleret socio-demografiske data om uddannelse og indkomst, spørgsmål om livssyn, angst for smitte og de tre eksistentielle profiler med hinanden, som kan ses i tabel 6.10. Derudover har vi korreleret profilerne med corona-relateret, ritualiseret adfærd i form af håndvask, afspritning og deltagelse i Philip Fabers morgensang. I tabellen er alle variable vendt således, at det går fra mindre til mere, dvs. positiv korrelation betyder positiv sammenhæng, negativ korrelation negativ sammenhæng.

Tabel 6.10. Korrelationer mellem de tre eksistentielle profiler, socio-demografi, livssyn og adfærd. Pearsons korrelation

\begin{tabular}{llll}
\hline & Håb og tillid & Øget mening & Eksistentiel krise \\
\hline Alder & 0.04 & $-0.13^{* *}$ & $-0.39^{* *}$ \\
Uddannelse & $-0.09^{* *}$ & -0.02 & $-0.17^{* *}$ \\
Personlig indkomst & -0.00 & -0.02 & $-0.08^{*}$ \\
Smittefrygt & $0.20^{* *}$ & $0.06^{*}$ & $0.19^{* *}$ \\
Religiøsitet & 0.05 & $0.12^{* *}$ & $0.14^{* *}$ \\
Morgensang & $0.19^{* *}$ & $0.09^{* *}$ & 0.02 \\
Håndvask & $0.09^{* *}$ & $0.08^{*}$ & -0.02 \\
Afspritning & $0.14^{* *}$ & 0.05 & 0.03 \\
\hline$* 00.05,{ }^{* *} p<0.01$ & & &
\end{tabular}




\section{Karakteristik af de eksistentielle profiler}

Når vi kigger på resultaterne for de tre profiler, finder vi, at personer der scorer højt på: Håb og tillid, generelt er højere uddannet, men findes på tværs af alle aldersgrupper. De udviser en signifikant bekymring over smittefaren og deltager oftere i morgensang og vasker eller spritter også oftere hænder. Det er altså personer, der generelt har håb for fremtiden og bakker op om de tiltag, der er udstukket ift. sikkerhedsadfærd - men også fællesskabsdannende aktiviteter som Philip Fabers morgensang.

Øget mening er ikke specielt relateret til uddannelsesniveau eller indkomst, men viser sig oftere blandt de unge. De har ikke så høj bekymring om smittefaren som den forrige profil. De deltager oftere i morgensang og vasker oftere hænder. Vi kan tolke, at det er personer, som tilsyneladende ikke føler sig så truede af smittefaren, men alligevel melder sig ind i fællesskabets tilbud om fællessang og påtager sig et eget ansvar for høj håndhygiejne.

Krise er forbundet med lavere indkomst, lavere uddannelsesniveau, og yngre alder og stærk forbundet med mere smittefrygt. Personer, der scorer højt på denne faktor, deltager ikke specielt i de fællesskabende aktiviteter som morgensang og vasker eller afspritter hverken mere eller mindre. Fra de forudgående analyser ved vi, at personer, der scorede på højt på enkelt-udsagnet om eksistentiel krise, havde signifikant lavere mentalt vedbefindende. Vi kan altså tolke, at særligt personer med lavere social klasse udviser mere eksistentiel krise, mindre håb og tillid for fremtiden og mulige løsninger på krisen. Muligvis fordi de også er mere udsat for krisens konsekvenser eks. i form af fyringer. Personer, der er oplever mere krise, er markant generede af COVID-19pandemiens konsekvenser og bekymrede for smittefaren. Samtidig er de tilbøjelige til ikke at melde sig ind i fællesskabet omkring håndteringen af corona-krisen og står måske mere sårbare i forhold til håndteringen af deres egen og samfundets krise.

\section{Religiøst livssyn og de eksistentielle profiler}

Sluttelig kan vi undersøge, om et religiøst livssyn falder sammen med en eller flere af profilerne. Vi har anvendt variablen, der samler graden af religiøs praksis samt personers angivelse af, hvor vigtig religion er for personen (se kapitel 4). Vi finder, at religiøsitet ikke er specielt relateret til profilen "Håb og tillid". Til gengæld er der en mindre, men signifikant sammenhæng mellem religiøsitet og både "Øget mening" og "Krise".

Den videnskabelige litteratur finder oftest, at personer med integreret religiøs praksis klarer sig godt i forbindelse med kriser i form af mindre personlig krise og højere mening (Schnell 2020). I analysen her finder vi så, at begge dele er tilfældet under COVID-19. Igen er det værd at bemærke, at øget mening og øget krise kan være tilfældet på samme tid. Vi er ikke i stand til at undersøge troens og de medfølgende praksissers indvirkning på mening og krise ved den måde, vi har spurgt. Nogle hypoteser fra religionspsykologien ligger imidlertid lige for: For nogle troende kan det tænkes, at der er karakteristika ved trolivets indhold og integritet, der gør, at de troende har lettere ved at finde mening, opleve accept, øget nærhed til andre og til det, 
der betragtes som guddommeligt. Sådanne karakteristika sammenfattes i den faglige begreb om positiv religiøs coping (Pargament 1997) Positiv religiøs coping er empirisk fundet forbundet med hensigtsmæssig tilpasning i forbindelse med kriser og til et mere stabilt psykisk velbefindende (la Cour 2005). For andre troende er troen mere disintegreret og kan rumme elementer af tvivl, oplevelse af distance til det guddommelige og skyld og straf, selv i et sekulariseret samfund som det danske (Pedersen, Pargament, Pedersen \& Zachariae 2013). I litteraturen er dette beskrevet som en tro præget af konflikt (spiritual struggle, Exline 2013). Ser vi på profilen "Krise" er det netop nogle af disse elementer, der er i spil (skyld, konflikt, distance). Det kan derfor tænkes, at selvom man har en religiøs tro og livsførelse, er der stor forskel på, om denne fungerer som kilde til mening og tilpasning eller nærmere er med til at forstærke en eksisterende krise. Ud fra disse hypoteser afspejler den oplevede øgede mening og den oplevede krise i mening altså to forskellige former for religiøsitet, der medvirker til henholdsvis resiliens (modstandsdygtighed) og sårbarhed hos de enkelte. Andre hypoteser kan imidlertid også komme på tale, eksempelvis den antagelse, at troslivet giver de samme mennesker modsatrettede signaler: Der er vitterligt håb og tillid til fremtiden at finde i troslivet; men samtidig er den sædvanlige copingmekanisme, nemlig øget socialitet og den ritualiserede, regelmæssige kirkegang, blevet frataget som mulighed eller den har ændret til ukendelighed, hvilket ikke giver den faste struktur og trygheden ved den. På tværs af kulturer har man fundet, at en øget samvittighedsfuldhed er tæt forbundet med religiøsitet (Gebauer et al. 2014). Samvittighedsfuldheden kan også give dobbelte signaler: De troende bekymrer sig mere om smitte og sygdom; men samtidig er tilliden mellem mennesker brudt, fordi andre mennesker både kan smitte og blive smittede, hvis de kommer for tæt på - det skaber øget afstand og mistillid for dem, der tager Sundhedsstyrelsens smitteforebyggende vejledninger mere alvorligt end andre.

\section{Konklusion}

I dette kapitel så vi, at eksistentielle temaer i høj grad blev aktiveret hos den danske befolkning i starten af COVID-19-krisen, og at de gav sig udtryk i forskellige eksistentielle profiler og dertilhørende adfærd. Vi så også, at der var sammenhænge mellem oplevet mening, krise og mentalt velbefindende, og at visse grupper i højere grad end andre oplevede en krisetilstand. Vi fandt, at særligt de yngste aldersgrupper rapporterede om eksistentiel krise og mistrivsel (jævnfør artikel 5, "Helbred og trivsel") og i en sådan grad, at det må kalde på opmærksomhed og handling i forhold til at forebygge yderligere mistrivsel og intervenere hos de hårdest ramte personer.

Det er meget sandsynligt, at det danske sundhedsvæsen kommer til at mærke en stigning i henvendelser om psykisk mistrivsel, som er direkte relateret til COVID-19. COVID-19 kan for nogen være den udløsende eller forstærkende begivenhed for såvel depression, angst, stress-tilstande og OCD-relaterede sygdomme som eksempelvis helbredsangst (sygelig angst for sygdomme, man frygter at få). 
Det nedsatte psykiske velvære og den hyppigere forekomst af eksistentiel krise sætter formentlig store fremtidige krav til de instanser, der kan påvirke og behandle danskernes mentale og eksistentielle trivsel, såsom sundhedsvæsen, kirkesamfund og kulturliv. Her vil en øget bevidsthed og præcision omkring, hvilke problemstillinger der er nye og karakteristiske i COVID-19-tiden være en stor hjælp til en konstruktiv indsats på området. Det er vores håb, at herværende undersøgelse kan bidrage hertil. Vi ser frem til, at de kommende dataindsamlinger forhåbentlig vil kunne besvare nogle af mere komplekse og sofistikerede spørgsmål om danskernes eksistentielle habitus under COVID-19.

\section{LITTERATUR}

Damasio, Bruno Figueiredo, Sílvia Helena Koller \& Tatjana Schnell

2013 "Sources of meaning and meaning in life questionnaire (SoMe): Psychometric properties and socio-demographic findings in a larger Brazilian sample", Acta de Investigación Psicológica 3 (3), 1205-1227. https://doi.org/10.1016/S2007-4719(13)70961-X

Exline, Julie J.

2013 "Religious and spiritual struggles", in: Kenneth I. Pargament, Julie J. Exline \& James W. Jones, eds., APA Handbook of Psychology, Religion, and Spirituality (Vol 1): Context, Theory, and Research, 459-475. https://doi.org/10.1037/14045-025

Gebauer, Jochen E., Wiebke Bleidorn, Samuel D. Gosling, Peter J. Rentfrow, Michael E. Lamb \& Jeff Potter

2014 "Cross-cultural variations in big five relationships with religiosity: A sociocultural motives perspective", Journal of Personality and Social Psychology 107 (6), 1064-1091. https://doi.org/10.1037/a0037683

la Cour, Peter

2005 "Danskernes Gud i krise”, in: Morten Højsgaard Thomsen \& Hans Raun Iversen, eds., Gudstro $i$ Danmark, Anis, 59-82.

Pargament, K.I.

1997 The Psychology of Religion and Coping: Theory, Research, Practice, Guilford Press.

Pedersen, H.F., K.I. Pargament, C.G. Pedersen \& R. Zachariae

2013 "Religious coping and quality of life among severely ill lung patients in a secular society", International Journal for the Psychology of Religion 23 (3), 188-203. https://doi.org/10.1080/10508619.2012.728068

Pedersen, H.F., M.H. Birkeland, J.S. Jensen, T. Schnell, N.C. Hvidt, T. Sørensen \& P. la Cour

2018 "What brings meaning to life in a highly secular society? A study on sources of meaning, religiosity, and socio-demographics", Scandinavian Journal of Psychology, Dec. 59 (6), 678-690. https://doi.org/10.1111/sjop.12495

Schnell, Tatjana

2009 "The Sources of Meaning and Meaning in Life Questionnaire (SoMe): Relations to demographics and well-being", The Journal of Positive Psychology 4 (6), 483-499. https://doi.org/10.1080/17439760903271074

2011 "Individual differences in meaning-making: Considering the variety of sources of meaning, their density and diversity", Personality and Individual Differences 51, 667-673. https://doi.org/10.1016/j.paid.2011.06.006

2021 The Psychology of Meaning in Life, Routledge. https://doi.org/10.4324/9780367823160

Schnell, Tatjana, R. Gerstner, \& Henning Krampe

2018 "Crisis of Meaning Predicts Suicidality in Youth Independently of Depression", Crisis 39 (4), 294-303. https://doi.org/10.1027/0227-5910/a000503 
Sørensen, T., P. la Cour, L. Danbolt, H. Stifoss-Hanssen, L. Lien, V. DeMarinis., H.F. Pedersen \& T. Schnell

2018 "The sources of meaning and meaning in life questionnaire in the Norwegian context: Relations to mental health, quality of life, and self-efficacy", International Journal for the Psychology of Religion, 29 (1), 32-45. https://doi.org/10.1080/10508619.2018.1547614

Heidi Frølund Pedersen, ph.d., seniorforsker og psykolog Funktionelle Lidelser, Aarhus Universitetshospital

Peter la Cour, lektor, ph.d., specialist $i$ sundhedspsykologi Institut for psykologi, Københavns Universitet 